\title{
ピペラジニゥム環と $\boldsymbol{p}$-キシレン- $\alpha, \alpha^{\prime}-$ ジイル基から誘導さ扎る カチオンの $7,7,8,8$-テトラシアノキノジメタン塩の電導性
}

(1973 年 12 月 6 日受理)

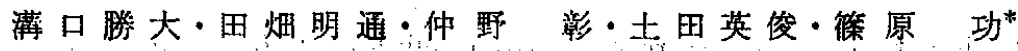

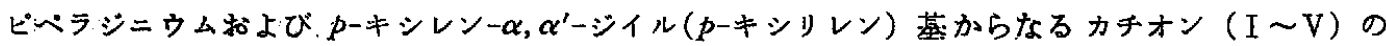
$7,7,8,8$-テトラシアノキノジメタン (CQ) 塩を合成し，此抵抗 $\rho$ 括よび䉓尊の活性化ェネルギー $E_{\mathrm{a}}$ を 測定した。

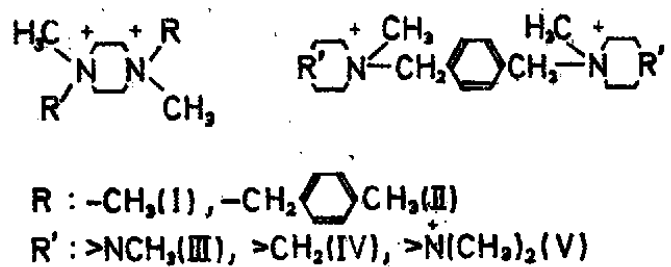

$\mathrm{CQ}$ simple salt の は, いずれも $10^{7} \Omega \cdot \mathrm{cm}$ と大きいが, 中性の $\mathrm{CQ}\left(\mathrm{CQ}^{0}\right)$ を添加した complex salt では, I -CQ $\left(3.2 \times 10^{5} \Omega \cdot \mathrm{cm}\right)>\mathrm{II}-\mathrm{CQ}\left(1.1 \times 10^{8}\right) \gg \mathrm{V}-\mathrm{CQ}\left(7.4 \times 10^{2}\right)>\mathrm{N}-\mathrm{CQ}(81)>\mathbb{H I}-\mathrm{CQ}(44)$ の順に $\rho$ 注いちじるしく減少する。 simple salt の $N, N$-ジメチルホルムアミド(DMF) やアセトニト リル飞対する溶解性は, complex salt 合成の必要条件であり, III-CQ $\approx N-C Q>I I-C Q 》 I-C Q \gtrsim V-$

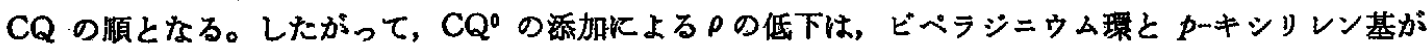
組み合わさってはじめて発現し，p-キシリレン基によるイオン席間隔の保持と溶解性の增大性 $\mathrm{CQ}^{0}$ と $\mathrm{CQ}^{*}$ の錯形成に，ピペラジンムム謤は $\mathrm{CQ}^{0} \cdot \mathrm{CQ}$ `のカチオンへの配列を規制して電導珄に寄与すると 推定した。

\section{1 耖言}

著者らは，高分子ポリカチオンの $7,7,8,8$-テトラシテノキノ ジメタン (以下 CQ と略記する) 塩の電導性飞腾する研究結果か 54)8)16)，ピベラジニウム環と $p$-キシレンー $\alpha, \alpha^{\prime}$-ジイル(以下，

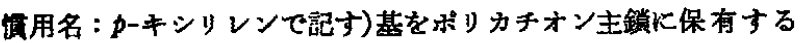
$\mathrm{PiX}-\mathrm{CQ}$ 塩"が，22 $\Omega \cdot \mathrm{cm}$ とるっとも低い比抵抗值を示し，さら に，解传中成獏性などの加工性にすぐれているため実用電子材 料としての溚在性があることなどを見いだして報告しだ。しか

1）この都文を“電導高性分子錯体の研究（第 9 垠）とする。

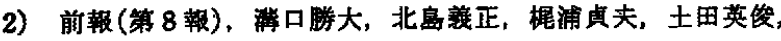
符原 功，日化，1974，1751.

* 早稲田大学理工学部, 160 東京都新宿区西大久保

3） ボリ( $N$-キシリレン, $N, N^{\prime}$-ジメチルピベラシニウム)-7,7, 8,8-テトラシフノキノジタン塩の略称で, この simple salt の䜊造式を次式で示す.<smiles>CCC(C)(CP)CN1C(=O)N(C)C2(CC)CCC1C2[O+]</smiles>

4) 宾田 茎、岩沢 晃，土田资俊，籍原功，日化，1974， 961 .
し、この理由, とくに, ボリカチオンの化学構造とこれら物性の 相関についてはいまだ不明確な点が多い。また，この相関仙高電 導性高分子錆体の分子設計上きわめて重要でかつ與味ある情報を 提供する。

本報では， $\mathrm{PiX}-\mathrm{CQ}$ 塩の低分子モデル化合物として，ピペラ ジニウムやp-キシリレン基から構成される 5 種類のカチオン-CQ 塩を合成し，その電学性，就よびこれに関連する溶解性中結晶性 なとをカチオンの化学構造と相関させながら，各結合基のむたら す奻果について考察した。また，電尊性の究明の一基として，可 視吸取スペクトルから $\mathrm{CQ}$ complex salt 中の中性 $\mathrm{CQ}\left(\mathrm{CQ}^{\circ}\right)$ と $\mathrm{CQ}$ アニオンラジカル (CQ⿱艹) のモル比 $\left[\mathrm{CQ}^{0}\right] /\left[\mathrm{CQ}^{-}\right]$を、電子ス ピソ共翵吸収スペクトルからカチオン $\mathrm{CQ}$ 塩の不対電子の蕞度 $N_{\mathrm{R}}$ とg 值を決定した。

\section{2 实倹}

\section{1 モデル化合物の選択}

本実験では，PiX-CQ 塩の低分子モデル化合物として，ピペラ ジニウム環や p-キシリレン黌からなる 5 種類のカチオンーCQ 塩 を合成した。すなわら，ピペシジニウム環から構成されるカチオ ソ-CQ 塩として， $N, N, N^{\prime}, N^{\prime}$ テトラメチルピペラジニウム 7 , 7,8,8-テトラシアノキノジメタン㙁（以下これを I - CQ 塩と略 記する）を，I-CQ 塩のカチオンの N 囬換基である 4 個のメチ 
ル基のらち 2 個を $p$-キシリル基で置换した $N, N^{\prime}$-ジメチル, $N, N^{\prime}-p$-キシリルピペラジニウム $-7,7,8,8$-テトラシアノキノジ メタン塩 (以下これを II-CQ 塩と略記する)，2 個のピペラジニ ウム環が $p$-キシリレン基で隔ったカチオン储造の $\alpha, \alpha^{\prime}-p$-キシ

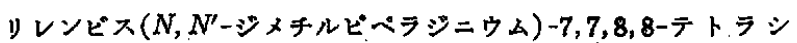
フノキノジメタ塩 (以下 III $-\mathrm{CQ}$ 塩と略記する), :III $-\mathrm{CQ}$ 塩の ピペラジニウム環に代成り，ピペリジニウム環を㸂入した $\alpha, \alpha^{\prime}-$ p-キシリレンビス(N-メチルピペリジニウム)-7, 7,8,8-テトラシ アノキノジメタン塩 (以下 $\mathrm{N}-\mathrm{CQ}$ 塩之略記する), さらに III-CQ 塩の末端三級空素原子をメチル基で四級化したカチオン棈造の $\alpha, \alpha^{\prime}-p$-キシリレンビス $\left(N, N^{\prime}, N^{\prime}\right.$-トリメチルピペラジニウム)7,7,8,8-テトラシナノキノジメタン塩（以下 $\mathrm{v}-\mathrm{CQ}$ と略記する） を選択し，合成した。それそれれの試料のカヂオン棈造とその略昂 を表1にまとめて示した。

\section{2 低分子カチオン-CQ 㙁の合成}

2.2.1 低分子カチオン-ハロゲン盐：低分子カチオンーハロゲ ン塩は，通常の Menschutkin 反忘にしたがい，第三級アミンと ハロダン化合物から合成したら。5種類の試料の合成の反応式を (1) （5）式に，合成条件，合成結果および生成物の元素分析 値を表 2 に示す。
Table 1 Cation structures

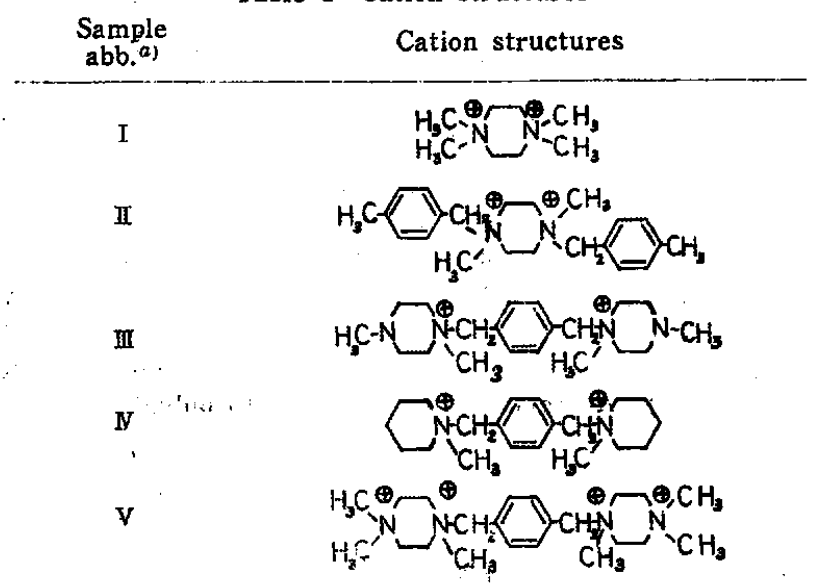

a) Abbreviation.

生成物の元素分析値は計算值と一致し，カチオンは㫹定の構造 であることを確認した。

2.2.2 カチオン-CQ simple salt : カチオン-CQ simple salt

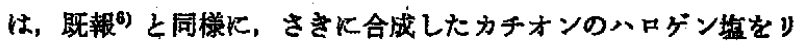

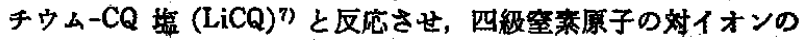

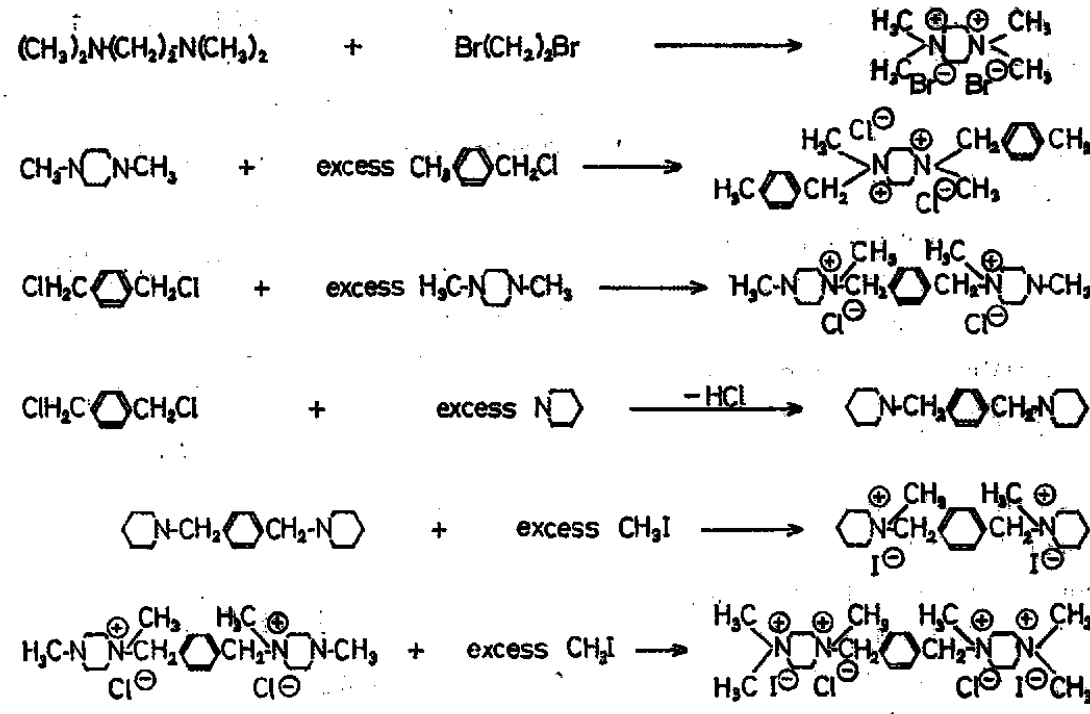

Table 2 Preparation of cation.

\begin{tabular}{|c|c|c|c|c|c|c|c|c|c|c|c|c|c|c|c|}
\hline \multirow{3}{*}{$\begin{array}{l}\text { Sample } \\
\text { abb.a) }\end{array}$} & \multicolumn{2}{|c|}{$\begin{array}{c}\text { Monomer } \\
\text { concentration }\end{array}$} & \multirow{3}{*}{$\begin{array}{l}\text { Sol- } \\
\text { vent }\end{array}$} & \multirow{3}{*}{$\begin{array}{l}\text { Temp. } \\
\left({ }^{\circ} \mathrm{C}\right)\end{array}$} & \multirow{3}{*}{$\begin{array}{c}\text { Reac- } \\
\text { tion } \\
\text { time } \\
(\mathrm{hr})\end{array}$} & \multirow{3}{*}{$\begin{array}{l}\text { Yield } \\
(\%)\end{array}$} & \multicolumn{8}{|c|}{ Elemental analysis } & \\
\hline & \multirow{2}{*}{$\begin{array}{l}\text { Amine } \\
(\mathrm{mol} / l)\end{array}$} & \multirow{2}{*}{$\begin{array}{c}\begin{array}{c}\text { Haloge- } \\
\text { nide } \\
(\mathrm{mol} / \mathrm{l})\end{array} \\
\end{array}$} & & & & & \multicolumn{4}{|c|}{ Found $(\%)$} & & \multicolumn{4}{|c|}{ Calcd. (\%) } \\
\hline & & & & & & & $\mathrm{C}$ & $\mathbf{H}$ & $\mathrm{N}$ & $\mathrm{x}$ & & C & $\mathrm{H}$ & $\mathrm{N}$ & $\mathrm{X}$ \\
\hline I & 0.89 & 0.89 & DMSO & 40 & 6 & 88.0 & 31.36 & 6.86 & 9.12 & 52.7 & $\mathrm{C}_{8} \mathrm{H}_{20} \mathrm{~N}_{2} \mathrm{Br}_{2}$ & 31.60 & 6.63 & 9.21 & 52.56 \\
\hline II & 0.50 & 3.0 & DMF & 40 & 30. & 97.2 & 66.74 & 8.34 & 7.01 & 17.8 & $\mathrm{C}_{22} \mathrm{H}_{92} \mathrm{~N}_{2} \mathrm{Cl}_{2}$ & 66.83 & 8. 16 & 7.08 & 17.93 \\
\hline III & 3.2 & 0.12 & $\mathrm{CH}_{3} \mathrm{OH}$ & 80 & 120 & 97.8 & 59.51 & 9.02 & 13.90 & 17.5 & $\mathrm{C}_{20} \mathrm{H}_{36} \mathrm{~N}_{3} \mathrm{Cl}_{2}$ & 59.54 & 8.99 & 13.89 & 17.58 \\
\hline $\mathbf{N}$ & 0.07 & 0.35 & $\mathrm{CH}_{3} \mathrm{OH}$ & 40 & 120 & 84.8 & 43.20 & 6.55 & 4.96 & 45.5 & $\mathrm{C}_{20} \mathrm{H}_{34} \mathrm{~N}_{2} \mathrm{I}_{2}$ & 43.24 & 6.49 & 5.01 & 45.45 \\
\hline $\mathrm{V}$ & 0.15 & 0.50 & $\mathrm{CH}_{8} \mathrm{OH}$ & 40 & 120 & 88.6 & 38.61 & 6.19 & 8.11 & 47.1 & $\mathrm{C}_{23} \mathrm{H}_{43} \mathrm{~N}_{3} \mathrm{Cl}_{2} \mathrm{I}_{2}$ & 38.45 & 6.16 & 8.15 & 47.24 \\
\hline
\end{tabular}

5) E. Tsuchida, K. Sanada, K. Moribe, Makromol. Chem., 151, 207(1972).

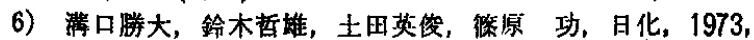
1751.
7) L. R. Melby, R. J. Harder, W. R. Hertler, W. Mahler, R. E. Benson, W. E. Mochel, J. Amir. Chem. Soc., 84, 3374 (1962). 
Table 3 Preparation of cation-CQ simple salts ${ }^{a}$ )

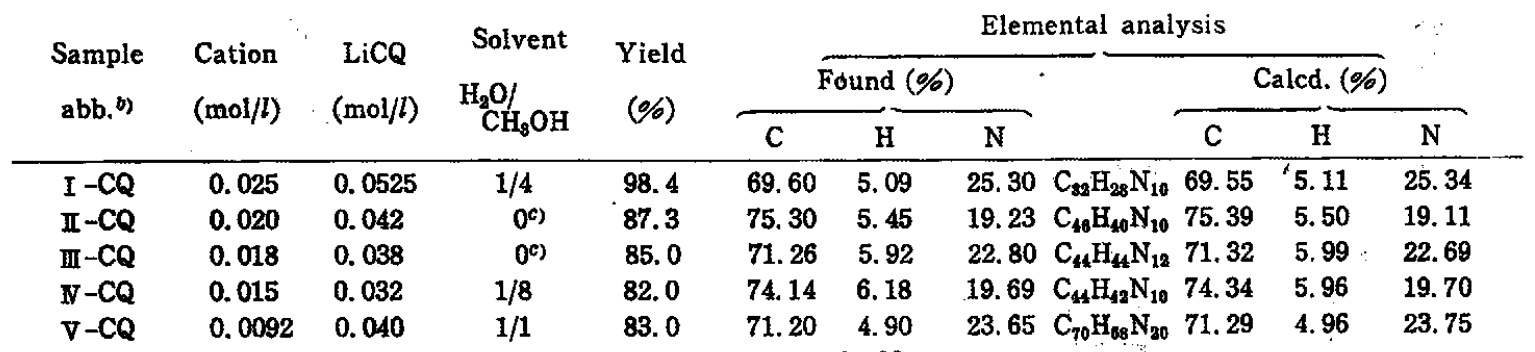

a) Reaction time ; $2 \mathrm{hrs}$, Reaction temp.; room temp., in $\mathrm{N}_{2}$ gas.

b) Abbreviation. c) $\mathrm{CH}_{8} \mathrm{OH}$ only.

交渙反応により合成した。それぞれの試料の合成条件，合成結果 および生成物の元莱分析值を表 3 に示した。生成物の構造は，元 莱分析值，赤外與収スベクトル，可視吸取スペクトルから同定し， 所定の杽造であることを磪認した。

以下K CQ simple salt の合成の一例として, II-CQ simple salt の合成実検を示す。反応式 (3) 飞よって合成したカチオン一 ハロダン埴 $6.9997 \mathrm{~g}(0.0173 \mathrm{~mol})$ を精製メタノール $100 \mathrm{ml}$ K、 溶解し、これにリチウム-CQ 塩 $7.7084 \mathrm{~g}(0.0355 \mathrm{~mol})$ をメタノ ール $400 \mathrm{ml}$ k溶解した溶液を加兄て反応させる。反応性，窒素 ガス導入管，カキマゼ装艮を储えた四つロフラスコ中で，空慗ガ

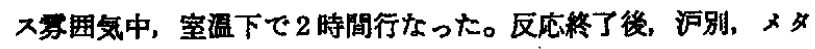

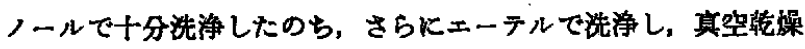
した。

Simple salt の溶解性㤝, complex salt の合成, 結晶体の生成

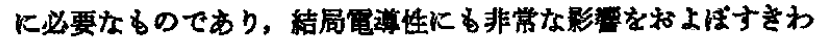
めて重要な物性である。I-CQ, V-CQ simple salt 恄, $N, N^{\prime}$-沙

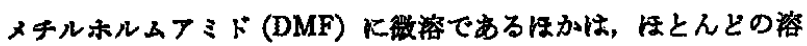
削化不溶であり，II-CQ， II-CQ，N-CQ simple salt は，高誘 電率の溶媒であるアセトニトリル，DMF， $N, N^{\prime}$-ジメチルスルホ キシド (DMSO) なととに恃すぐれた溶解性を示す。このようにカ チオン構造により，溶解性はいらしるしく異なる。

2.2.3 カチオン-CQ complex salt : CQ complex salt simple salt $K \mathrm{CQ}^{0}$ を添加（dope）して合成与る。而-CQ およ び N-CQ complex salt $は$ は, simple salt のアヤトニトリル溶液

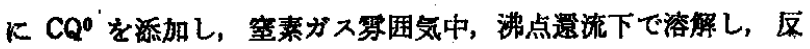
态させる。生成物恃，いずれる暗青色～黑色の針状結晶である。 I $-C Q$, II $-C Q$ および V-CQ complex salt は，DMFを用いて

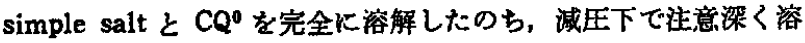

媒を除去し，真空障嬠した。表 4 KCQ complex salt の光素分 析值を示し，粠造の確認をした。

\section{3 スベクトルの測定}

赤外吸収スペクトルは $\mathrm{KBr}$ 鋎剂法により, 日立 EPI-G 3 型赤 外吸收分光光度計で，可視吸収スペクトルはナセトニトリル溶液 めるいは DMF 溶液で，島津 MPS 50 型電子吸収分兆光度計を 用いて測定した。䉓子スピン共鳴吸収スペクトルは，澌定陚料と して粉矽陚料を $\mathrm{KCI} て ゙$ 希釈したすのを, 標準試料としてジフェ ニルピクリルヒドラジル (DPPH) を用いて，日本電子製 JES-

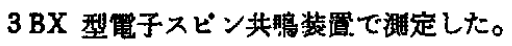

\section{4 比抵抗およひ電算の活性化エネルギーの测定}

比抵抗 $の$ の測定は既報名 にしたがい，タブレット状陚料とし直

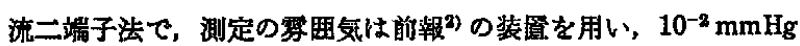
の真空下で行なった。な扰，比抵抗 $\rho$ は次式から求めた。

$$
\rho=\pi l^{2} R / 4 d
$$

ここで，lはタブレット試料の直径、 $d$ は厚さ，Rは抵抗の実 测値を示す。

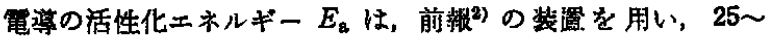
$125^{\circ} \mathrm{C}$ の抵抗の温度変化から次式化より求めた。

$$
R=R_{0} \exp \left(E_{\mathrm{a}} / k T\right)
$$

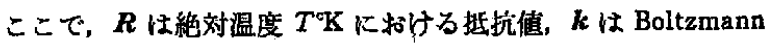
定数である。

\section{3 結 果と教察}

\section{1 スベクトル分析}

3.1 .1 可視吸収スベクトル：图 1 K中性 $\mathrm{CQ}\left(\mathrm{CQ}^{0}\right)$ お よび孟一 CQ simple salt, complex salt のアセトニトリル溶液の可視爱

Table 4 Elemental analysis of cation-CQ complex salts

\begin{tabular}{|c|c|c|c|c|c|c|c|c|}
\hline \multirow{3}{*}{$\begin{array}{l}\text { Sample } \\
\text { abb. }\end{array}$} & \multirow{3}{*}[\mathrm{CQ}^{0}]{$/\left[\mathrm{CQ}^{2}\right]$} & \multirow{2}{*}{\multicolumn{4}{|c|}{ ound (\%) }} & \multirow{2}{*}{\multicolumn{3}{|c|}{ Calcd. $(\%)$}} \\
\hline & & & & & & & & \\
\hline & & $\mathrm{C}$ & $\mathrm{H}$ & $\mathbf{N}$ & & c & $\mathrm{H}$ & $\mathrm{N}$ \\
\hline $\mathrm{I}-\mathrm{CQ}$ & $0.5^{b)}$ & 69.72 & 4.29 & 25.99 & $\mathrm{C}_{44} \mathrm{H}_{92} \mathrm{~N}_{14}$ & 69.83 & 4.26 & 25.91 \\
\hline II-CQ & $0.5^{b)}$ & 74.90 & 3.89 & 21.20 & $\mathrm{C}_{68} \mathrm{H}_{46} \mathrm{~N}_{14}$ & 74.35 & 4.73 & 20.92 \\
\hline III $-C Q$ & $1.0^{c)}$ & 71.05 & 4.63 & 24.32 & $\mathrm{C}_{68} \mathrm{H}_{82} \mathrm{~N}_{20}$ & 71.07 & 4.56 & 24.37 \\
\hline $\begin{array}{l}\mathbf{N}-\mathrm{CQ} \\
\mathrm{v}-\mathrm{CQ}\end{array}$ & $\begin{array}{l}1.0^{c)} \\
\left.0.6^{b}\right)\end{array}$ & $\begin{array}{l}72.80 \\
69.93\end{array}$ & $\begin{array}{l}4.76 \\
5.62\end{array}$ & $\begin{array}{l}22.42 \\
24.45\end{array}$ & $\begin{array}{l}\mathrm{C}_{68} \mathrm{H}_{50} \mathrm{~N}_{18} \\
\mathrm{C}_{09} \mathrm{H}_{68} \mathrm{~N}_{30}\end{array}$ & $\begin{array}{l}72.97 \\
71.08\end{array}$ & $\begin{array}{l}4.50 \\
4.08\end{array}$ & $\begin{array}{l}22.53 \\
24.84\end{array}$ \\
\hline
\end{tabular}

Elemental analysis

a) Abbreviation.

b) These samples were prepared in DMF solvent.

c) These samples were crystalized from acetonitrile solvent.

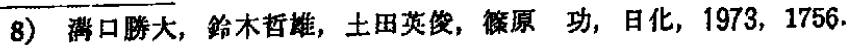




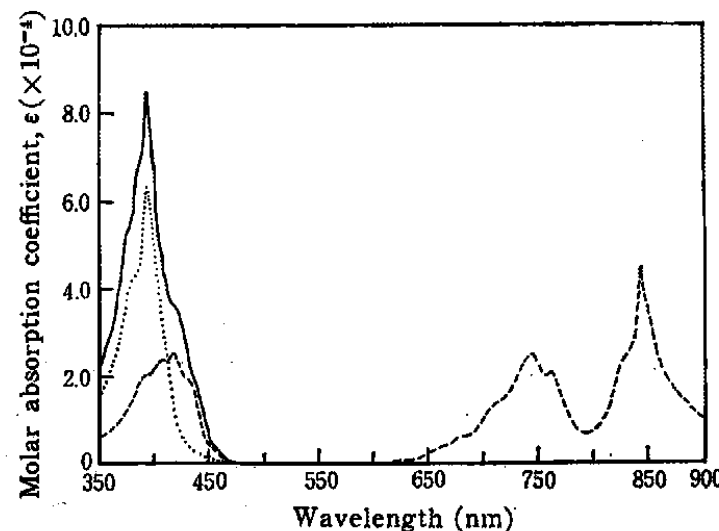

Fig. 1 Visible absorption spectra $\left(10^{-5} \mathrm{~mol} / \mathrm{l}\right)$ in acetonitrile

- II $-\mathrm{CQ}^{0} \cdot \mathrm{CQ}^{\circ}, \ldots$ : III $-\mathrm{CQ}^{\top}, \cdots \cdots: \mathrm{CQ}^{0}$

収スペクトルを，モル吸光係数 とと波長 $\lambda$ の関係で示した。CQ0 は $394 \mathrm{~nm}$ に四収極大を, simple salt は420,744, $842 \mathrm{~nm}$ に, complex sait 恃 394, 744, $842 \mathrm{~nm}$ にそれぞれ極大眀収を示す。 simple salt および complex salt の吸取スベクトルは III-CQ K

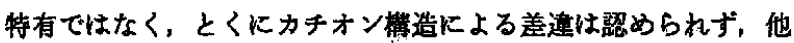
の低分子カチオン-CQ 塩でも同様な吸収スベクトルが観測され た。これらの吸收スペクトルは， $\mathrm{CQ}$ のアニオンラジカル $\left(\mathrm{CQ}^{\circ}\right)$ と $\mathrm{CQ}^{0}$ の吸収に帰属し，また， complex salt の吸収は， $\mathrm{CQ}^{0}$ と $\mathrm{CQ}=$ の重なりとして一致する。したがって, complex salt では, $\mathrm{CQ}^{0}$ と $\mathrm{CQ}^{\circ}$ は完全に分離した状態で存在し，可視領城での㖟収 は，それぞれの吸光度の暞として現われ，定贵的な加成性が認め られる。 simple salt の $420 \mathrm{~nm}$ でのそル㖟光俰数には, Melby $\zeta^{7)}$ が LiCQ で得た結果 $(\varepsilon=24300)$ と一致することから，IIICQ simple salt のピベラジニウムの対イオンは，塩化物イオン から CQ` へほぼ 100\% 交換した所定の構造であることが確諗で きた。ここで, $\mathrm{CQ}^{\circ} の 394 \mathrm{~nm}$ のモル曼光係数 $\varepsilon_{(394)}^{0}=63600$,

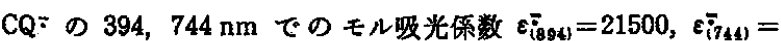
24400 を用いて， complex salt の吸収スペクトルから CQ の添 加モル比 $\left[\mathrm{CQ}^{0}\right] /\left[\mathrm{CQ}^{\top}\right]$ が算出できる。すなわら, complex salt の吸取スペクトルで吸取極大を示す波長 $394 \mathrm{~nm}$ では，CQ $\mathrm{CQ}^{0}$ と

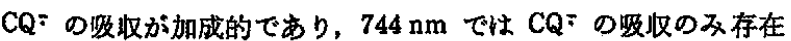
し， $\mathrm{CQ}^{0}$ の樶取がまったくないので， complex salt 中の $\mathrm{CQ}^{0}$ お

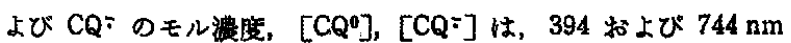

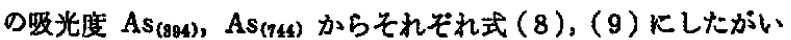
求められる。

$$
\begin{aligned}
& {\left[\mathrm{CQ}^{\top}\right]=\mathrm{As}_{(74) / \varepsilon^{-}{ }_{(7 \mathrm{u})}}} \\
& {\left[\mathrm{CQ}^{0}\right]=\left\{\mathrm{As}_{(994)}-\varepsilon^{-}{ }_{(884)}\left[\mathrm{CQ}{ }^{-}\right]\right\} / \varepsilon^{0}{ }_{(894)}}
\end{aligned}
$$

したがって，派加比 $\left[\mathrm{CQ}^{0}\right] /\left[\mathrm{CQ}^{\top}\right]$ は式 (10)のようになる。 $\left[\mathrm{CQ}^{0}\right] /\left[\mathrm{CQ}^{-}\right]=\left[\varepsilon^{-}{ }_{(744)} \cdot \mathrm{As}_{(894)}-\varepsilon^{*}{ }_{(894)} \cdot \mathrm{As}_{(744)}\right] / \mathrm{As}_{(744)} \cdot \varepsilon^{0}{ }_{(894)}$

ここで，式（10）を用い，直-CQ 特よび N-CQ complex salt の㖟収スベクトルから $\left[\mathrm{CQ}^{0}\right] /[\mathrm{CQ}=]$ を求めたところ，いずれる 1.0 なる結果を得, III $-\mathrm{CQ}$ およ゙ $\mathrm{N}-\mathrm{CQ}$ の complex salt の組 成を確認した。，complex salt の組成物の確認には，元装分析に よる方法もあるが，可視樶取スペクトルによる方が，より簡便で 正碓な組成比浹定法である。
3.1 .2 電子スビン共鳴 (ESR) スペクトル:CQ 塩の磁気的性 啠に関する ESR の報告市は多いが，ここでは，低分子カチオンー $\mathrm{CQ}$ 塩の電導性の究明の立場か $5, \mathrm{I}-\mathrm{CQ}, \mathrm{II}-\mathrm{CQ}$ simple salt t $^{-}$ よび添加比 1.0の III-CQ complex salt の ESR スペクトルを 測定し，不対電子の $g$ 值，および相対不奶電子数 $N_{\mathrm{R}}$ を求めた。 これら CQ 塩の吸取スペクトルはいずれる Lorentz 型であり,图 2 Kは I -CQ simple salt の ESR スペクトルを示した。また, ESR スペクトルより，DPPH を標準陚料として式(11)にしたが い $g$ 值を，既法行火より相対不対龟子数 $N_{R}$ を算出し，その結果 を表 5 に示した。

$$
g=g_{\mathrm{DPPH}}\left(1-\frac{\Delta H}{H_{0}}\right)
$$

ここで, $H_{0}$ は DPPH の吸取の中心磁場 (gauss) を， $\Delta H$ は 試料の中心磁场之 DPPH の中心嘫畦の差 (gauss)，g gPPH は DPPH の $g$ 值を示す。

これらカチオン-CQ simple salt の $g$ 值から，CQ广の不凉䉓 子は自由電子であること，不対電子数は Avogadro 数とほとんど 一政し、所定の構造であることおよび simple salt と complex salt の不対笔子がほとんど同等であることが判明した。ここで

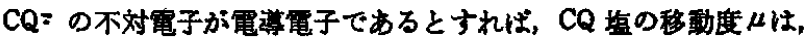

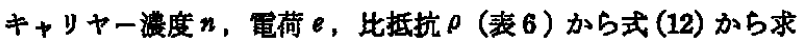
められる。その結果, 近 $-C Q$ simple salt の $\mu$ は $5.0 \times 10^{-2} \mathrm{~cm}^{2} /$

$$
\mu=1 / \text { nep }
$$

V.sec ときわめて小さいが, III-CQ complex salt は $1.2 \times 10^{-8}$ $\mathrm{cm}^{2} / \mathrm{V} \cdot \mathrm{sec}$ と比㜞的大い。この結果加ら, simple salt K添加 された $\mathrm{CQ}^{0}$ 恃電導電子の移動度の增加に奇与していると考えら れる。
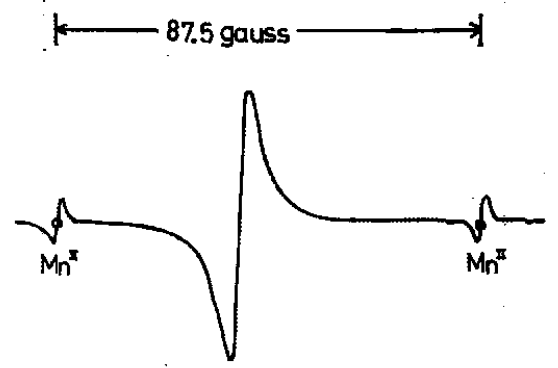

\begin{tabular}{|c|c|c|c|c|}
\hline $\begin{array}{l}\text { Sample } \\
\text { abb. }\end{array}$ & $\begin{array}{l}{\left[\mathrm{CQ}^{\circ}\right] /} \\
{\left[\mathrm{CQ}^{\circ}\right]}\end{array}$ & $\begin{array}{l}\text { Line width } \\
\text { (gauss) }\end{array}$ & $g$-Value & $\begin{array}{r}\text { Concentration } \\
\text { of ;unpaired } \\
\text { electron } N_{R} \\
\text { (electrons/mol) } \\
\times 10^{2 s}\end{array}$ \\
\hline$I-C Q$ & 0 & 4.67 & 2.0028 & 3.71 \\
\hline II $-\mathrm{CQ}$ & 0 & 4.66 & 2.0028 & 3.15 \\
\hline III $-C Q$ & 0 & 4.70 & 2.0026 & $\begin{array}{r}7.18 \\
75\end{array}$ \\
\hline & & 4.70 & 2.0026 & 10.75 \\
\hline
\end{tabular}

$\mathrm{H} \longleftarrow$

Fig. 2 ESR spectrum of I $-\mathrm{CQ}$ simple salt

Table 5 Results of ESR spectra of cation-CQ salts

9) D. B. Chesnut, H. Foster, W.D. Phillips, J.Chem. Phys., 34, 684(1961) ; D. B. Chesnut, W.D. Phillips, ibid., 35, 1002(1961) ; M. T. Jones, ibid., 40, 1837(1964).

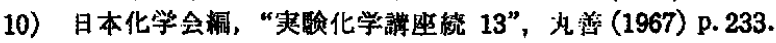




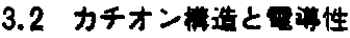

カチォン CQ simple salt および complex salt の抵抗の対数 $\log R$ と䋓対温度の逆数 $1 / T$ の閔係を园 3，4 にそれぞれぶし た。いずれの特合す，良好な任線性を示し、この薄線の勾配から

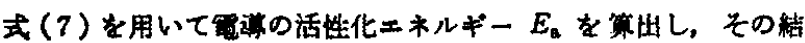
果をそれぞれのの値とあわせて数 6 に示した。

ピヘラジニウム理単独のカチオンから㭗成される I -CQ 塩の simple salt は比交的莗い $\rho$ 值 $5.1 \times 10^{\circ} \Omega \cdot \mathrm{cm}$ を示し，またこ

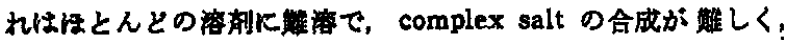

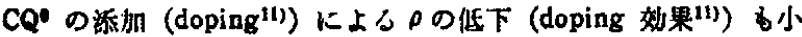

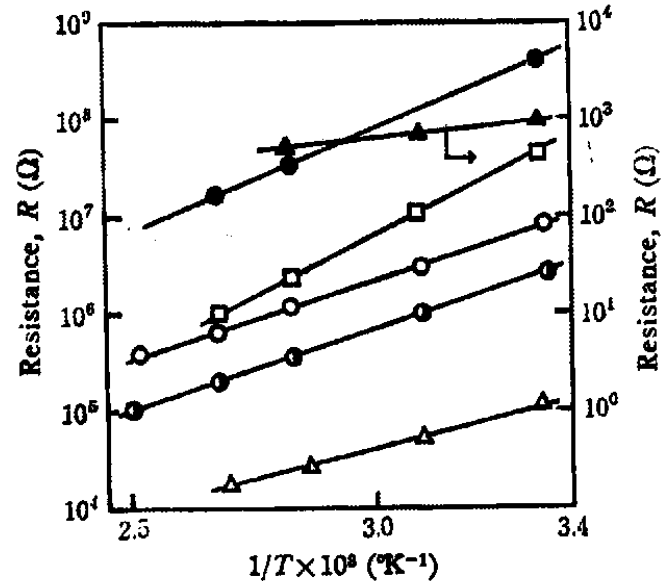

Fig. 3 Resistance vs. inverse absolute temperature for cation-CQ simple salts

$O:$ I - CQ, : II -CQ, O : II -CQ(Polycrystalline), $\triangle:$ III-CQ (Polycrystalline), $\square: \mathrm{N}-\mathrm{CQ}, \triangle: \mathrm{V}-\mathrm{CQ}$

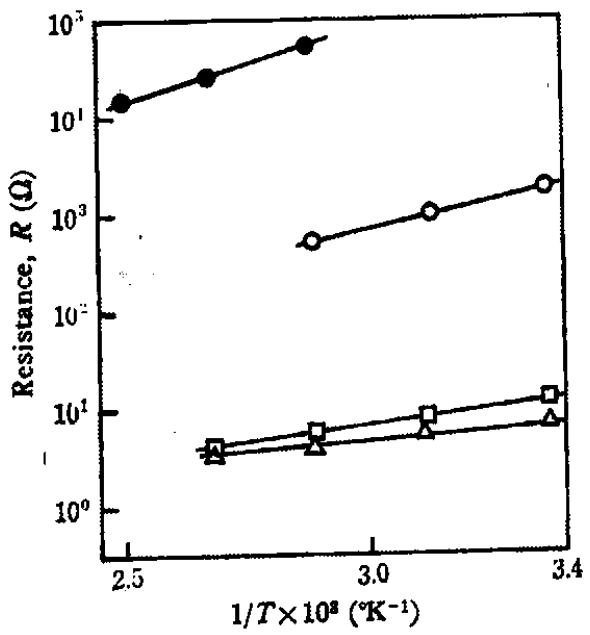

Fig. 4 Resistance vs, inverse absolute temperature for cation-CQ complex salts

$$
\begin{aligned}
& O: \text { I }-\mathrm{CQ}\left(\left[\mathrm{CQ}^{0}\right] /\left[\mathrm{CQ}^{-}\right]=0.5\right) \\
& : \text { II }-\mathrm{CQ}(0.3) \\
& \triangle: \text { III }-\mathrm{CQ}(1.0) \text { (Polycrystalline) } \\
& \square: \mathrm{N}-\mathrm{CQ}(1.0) \text { (Polycrystalline) }
\end{aligned}
$$

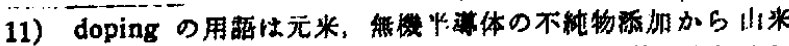

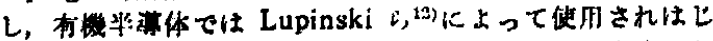

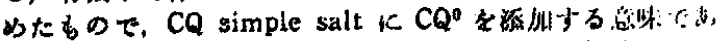

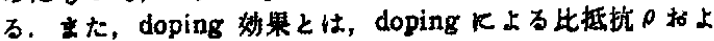

\begin{tabular}{|c|c|c|c|}
\hline $\begin{array}{c}\text { Sample } \\
\text { abb.a) }\end{array}$ & {$\left[\mathrm{CQ}^{0}\right] /\left[\mathrm{CQ}^{-}\right]$} & $\rho(\Omega \cdot \mathrm{cm})$ & $\begin{array}{c}E_{\mathrm{B}} \\
(\mathrm{eV})\end{array}$ \\
\hline $\mathrm{I}-\mathrm{CQ}$ & $\begin{array}{c}0 \\
0.5\end{array}$ & $\begin{array}{l}\text { 5. } 1 \times 10^{6} \\
\text { 3. } 2 \times 10^{8}\end{array}$ & $\begin{array}{l}0.31 \\
0.29\end{array}$ \\
\hline II $-\mathrm{CQ}$ & $\begin{array}{c}0 \\
0^{b 3} \\
0.5\end{array}$ & $\begin{array}{l}6.5 \times 10^{8} \\
1.0 \times 10^{8} \\
1.1 \times 10^{5}\end{array}$ & $\begin{array}{c}0.35 \\
0.20 \\
-\end{array}$ \\
\hline III $-C Q$ & $\begin{array}{l}0 \\
1.0 \\
1.0^{b j}\end{array}$ & $\begin{array}{l}1.0 \times 10^{4} \\
1.1 \times 10^{2} \\
4.4 \times 10^{1}\end{array}$ & $\begin{array}{l}0.30 \\
0.12 \\
0.096\end{array}$ \\
\hline$N-C Q$ & $\begin{array}{c}0 \\
\left.1.0^{b}\right)\end{array}$ & $\begin{array}{l}1.4 \times 10^{1} \\
8.1 \times 10^{1}\end{array}$ & $\begin{array}{l}0.51 \\
0.13\end{array}$ \\
\hline$V-C Q$ & $\begin{array}{c}0 \\
0.6 \\
1.0\end{array}$ & $\begin{array}{l}3.9 \times 10^{3} \\
7.4 \times 10^{2} \\
1.5 \times 10^{8}\end{array}$ & $\begin{array}{c}0.13 \\
- \\
-\end{array}$ \\
\hline
\end{tabular}

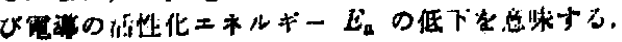

Table 6 Specific resistances $\rho$ and activation cnergies $E_{\text {a }}$ of cation-CQ salts

a) Abbreviation. b) Polycrystalline.

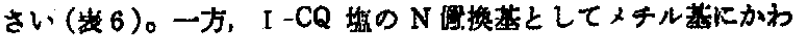

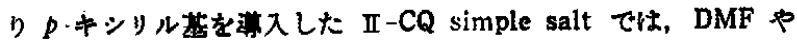
アセトニトリルなとの溶郕に対する㳑解性はいちしるしく增火 し， complex salt の合成性容物であったが，そのdoping 奻果は 低く，

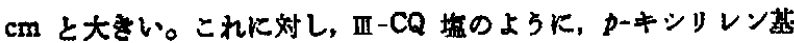

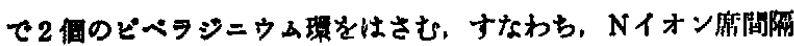
が pーキシリレン基で撛成されたカチオン楼造の simple salt の $\rho$ は, I -CQ ஓ II -CQ の simple salt とはとんと同等であるが， これはアセトニトリルなとの溶都易溶で，かつ $\mathrm{CQ}^{\circ} の$ daping 妼舆はいちじるしく大い。㳢加比 $\left[\mathrm{CQ}^{0}\right] /[\mathrm{CQ} \div]$ が 1.0 のと

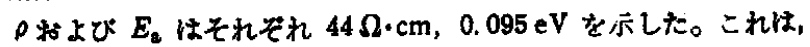

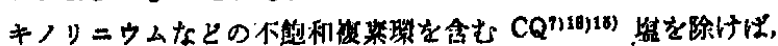

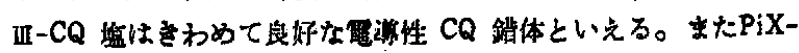

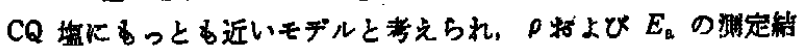
果す PiX-CQ complex salt の取小値 $22 \Omega \cdot \mathrm{cm}, 0.095 \mathrm{eV}$ と一

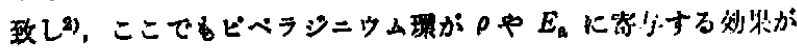
十分㤎められる。

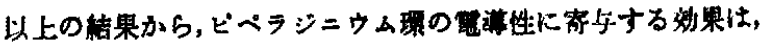
ピベョシニウム聚自身に起因ナるというよりはむしろ pーキシリ

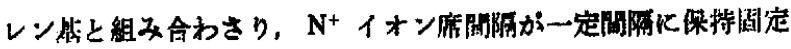
されてはじめて発現すると考えられる。一般にカチオン-CQ 塯

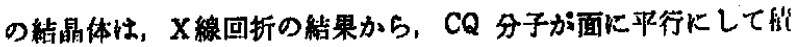
み直さなったカラムとカチオンのカラムが束状になっている㨫

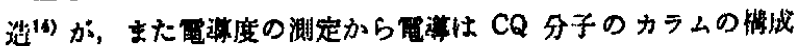

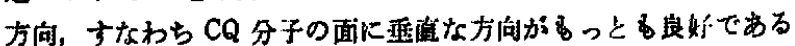

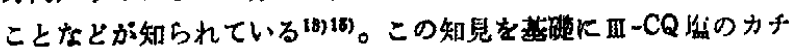

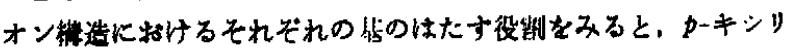

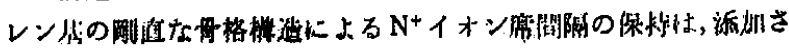

12) J. H. Lupinski, K. D. Kopplc, J. J. Hertz, J. Polym. Sci., Part C, 16, 1561(1967).

13) L. R. Melby, Can. J. Chem., 43, 1448(1965).

14) A. W. Hänson, Acta Crystallogr., 19, 610(1965); H. Kobayashi, F. Marumo, Y. Saito, ibid., B 27, 373(1971); T. Sundarson, S. C. Wallwork, ibid., B 28, 491 (1972).

15) C. J. Fritchie, Jr., ibid., 20, 892(1966). 


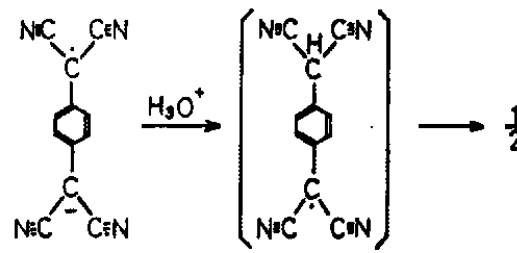

$\left(C Q^{\top}\right)$<smiles>N#CC(C#N)c1ccc(C(C#N)C#N)cc1</smiles>

$(\mathrm{CO})$

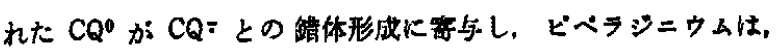
そのシクロヘキサン烟似㻆避による $\mathrm{N}^{+}$イオン磨固定のため, $\mathrm{CQ}^{0}$ と $\mathrm{CQ}=$ の錹体がカチオンへ配列するときこれを烧制し, $\mathrm{CQ}$ 分子のカラムの形成に乲!おると挷定される。

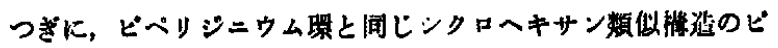

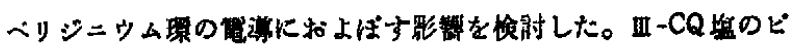

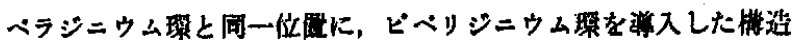
の $\mathrm{N}-\mathrm{CQ}$ 盐の simple sait $は ， \rho=1.48 \times 10^{\circ} \Omega \cdot \mathrm{cm}, E_{\mathrm{B}}=0.51$

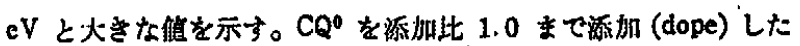

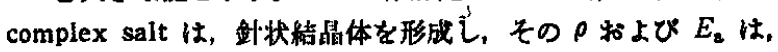
それぞれ $81 \Omega \cdot \mathrm{cm}, 0.13 \mathrm{eV}$ を示し，いちじるしいdoping 妙 果が觬測されだ。

このよらК, ピベリジニウム理とピベラジニウム環の比慗は, 低分子カチオンーCQ 㙁に拈いて，差建は蹋められるが，ボリカ

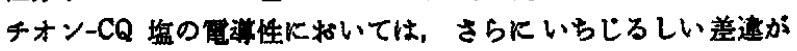

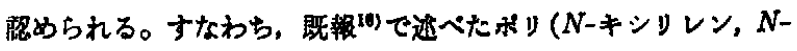
ピヘリジニウム) -7,7,8,8-テトラシアノキノジメタン塩（以下

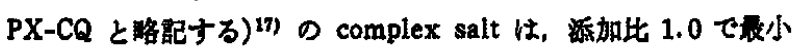
の比抵抗倠 $\rho_{\min } 4.8 \times 10^{8} \Omega \cdot \mathrm{cm}$ を，またのときの $E_{\mathrm{a}}$ は $0.146 \mathrm{eV}$ てある(10)。これは $\mathrm{PiX}-\mathrm{CQ}$ complex salt") の $22 \Omega \cdot \mathrm{cm}$, $0.095 \mathrm{eV}$ の䧸にくらべいちじるしく大い。このよらに, ボリ

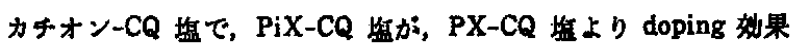
が大なる理由に，ピペヨジニウム溇の立体圽果とピベリジニウム 棵の $\mathrm{N}^{+}$イオン席の近傍の立体障害, すなわら, PX-CQ 㙁のポ

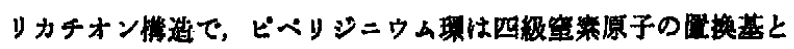

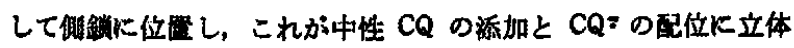
的な障苗となると考光られる。一方，PiX-CQ では，ピペラジ二 ウム德の 2 㮯の四級空意原子を主銧中下含み、これのシクロへキ サン数似構避による $\mathrm{N}^{+}$イオン庶の固定化の作用にさらに，p-キ

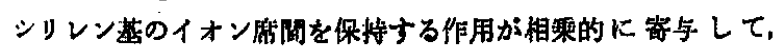

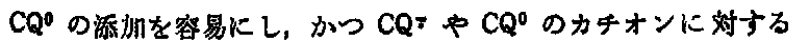

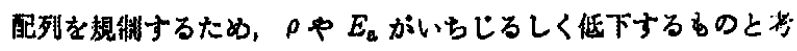
えられる。

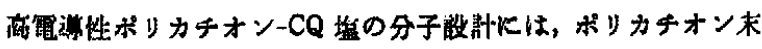

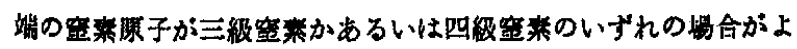

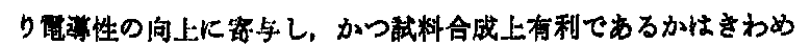

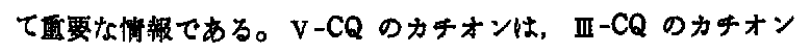

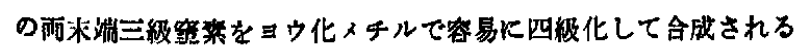

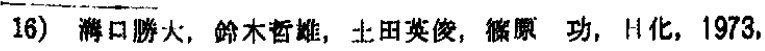
1765.

17) $\mathrm{PX}-\mathrm{CQ}$ simple salt の楼造式.

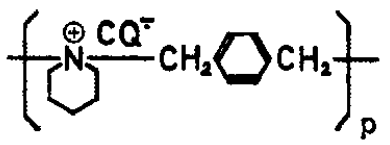

が，生成したハロゲン化物は，メタノールなとの非水溶媒に稓潘 であるため，CQ simple salt の合成には相当五の水溶媒を必曹 とする。多量の水が系内に存在すると，下莭の上うな $\mathrm{CQ}=$ の不 均化反心 (13) 加起こり, CQ が混在した simple salt となる゙)

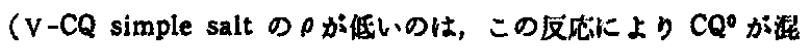
在しているためである)。主た，生成する simple salt は，仿と

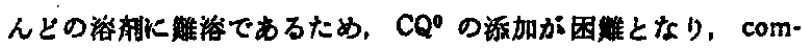
plex salt の生成には，これが大きな障害となる。表 5 から明ら

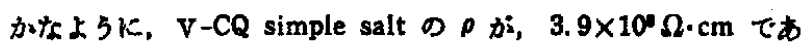
$\eta$, complex salt の

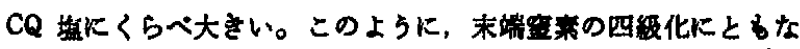

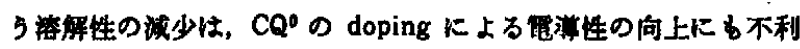
な結果をるたらす。PiX-CQ 塩のボリカチオン梅造は、ハロダン 分析の結果から，末端菱が，三级空案で終絬していると考えられ るか。したかって，PiX-CQ 韭でのそのすぐれた溶解性にとるな 5 doping 好果の榎位性の一端は，末端部の三級空菜に起因子万 とも教えられる。たた，重合度の大きな高分子では，この㚳果す かなり減少するであろらが，PiX-CQ 㙁のよろK，重合度が小さ いと考えられる亚合体では敝視できない因子となるわけてある。

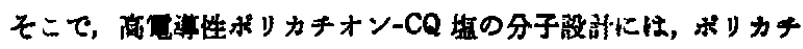
オンの末端部の四級化は避ける必要がある。

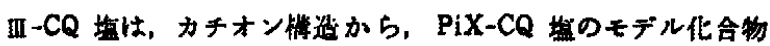

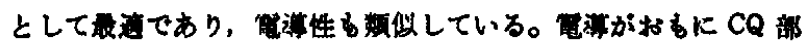
分でなされるといらことを考えれ恬，諴料の結晶性が绻者の方が

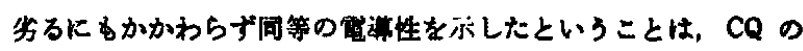

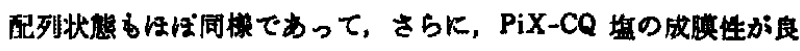

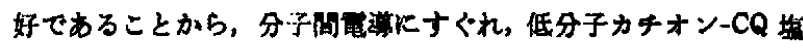

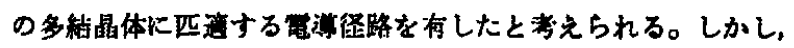
定量的な宛明には，X線回折なとによるカチオンと CQ 分于の眍

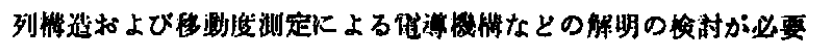
であろら。

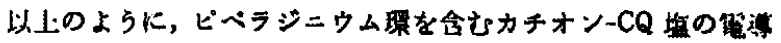

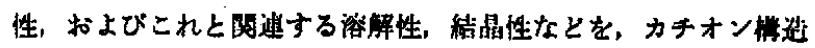

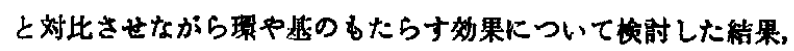
つぎの結秢を得た。

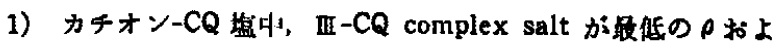
び $E_{\mathrm{a}}$ を灾し、ピペラジニウム棵によるค， $E_{\mathrm{a}}$ の doping 妙果

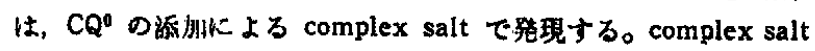
および simple salt の不対電子数に変化がないことから, $\mathrm{CQ}^{\circ} の$

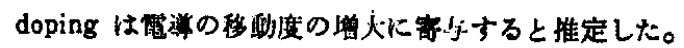

2）Complex salt の生成に上万電刑姓の向上のためには, simple salt の溶解性仙必没条件となる。カチオンの邽末端の空

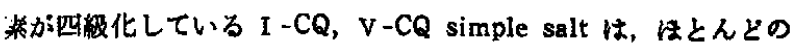

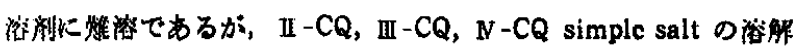


性は良好である。したがって，ポリカテオン-CQ 塩の分子設計に は、ポリカキオンの末端四級化はさけるべきである。

3）カチオン-CQ 塩の性質をカキオン構造と対比した結果, ピ ヘララジニウム環は, $p$-キシリレン基と組み合わさってはじめて。 および $E_{\mathrm{a}}$ の低下Kいちじるしい効果を発揮する。p-キシリレン 基は $\mathrm{N}^{+}$イオン席間隔の保持と simple salt の溶解珄の增大火笴
与して $\mathrm{CQ}^{0}$ の dope による $\mathrm{CQ}^{\circ}$ と $\mathrm{CQ}^{0}$ の錹形成を容易にし,

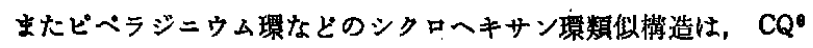
や $\mathrm{CQ}$ = のカチオ゙ンへの配列を規制する立体效果を有すると推定 した。

（1973 年 4 月，日本化学会第 28 年会（一部）詋演）

Electronic Conductivity of 7,7,8,8-Tetracyanoquinodimethane Salts

Containing Cation Derived from Piperadinium Ring and

$$
\boldsymbol{p} \text {-Xylene- } \alpha, \alpha^{\prime} \text {-diyl Group }
$$

Katsuhiro Mizoguchi, Akimichi Tabata, Akira Nakano,

Eishun Tsuchida and Isao Shinohara

Department of Polymer Chemistry, Waseda University; Nishiohktubo, Shinjuku-ku, Tokyo 160 Japan

$7,7,8,8$-Tetracyanoquinodimethane (CQ) salts containing cation derived from piperadinium ring and $p$-xylene- $\alpha, \alpha^{\prime}$-diyl ( $p$-xylylene) group were pnepared, and specific resistances $\rho$ and activation energies $E_{\mathrm{a}}$ of cation-CQ salts were measured.<smiles>[R][C@@H]1N(C)N([R])[N+]1(C)C</smiles>

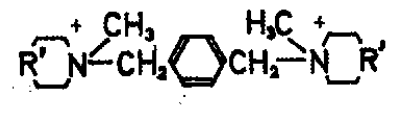

$$
\begin{aligned}
& \mathrm{R}:-\mathrm{CH}_{3}(1),-\mathrm{CH}_{2} \bigcirc \mathrm{CH}_{3}(\mathrm{II}) \\
& \mathrm{R}^{\prime}:>\mathrm{NCH}_{3}(\mathrm{II}),>\mathrm{CH}_{2}(\mathrm{IV}),>\mathrm{N}\left(\mathrm{CH}_{3}\right)_{2}(\mathrm{~V})
\end{aligned}
$$

The $\rho$-valuse of simple salts were almost ca. $10^{7} \Omega \cdot \mathrm{cm}$, and when neutral $\mathrm{CQ}\left(\mathrm{CQ}^{0}\right)$ was added to simple salts, the $\rho$-values decreased markedly, as follows;

$$
\begin{aligned}
& \text { Series : } \quad I-C Q>\text { II }-C Q \gg V-C Q>N-C Q>\text { III }-\mathrm{CQ} \\
& \rho(0 \cdot \mathrm{cm}): 3.2 \times 10^{8} \quad 1.1 \times 10^{6} \quad 7.4 \times 10^{2} \quad 81 \quad 44
\end{aligned}
$$

The solubility of simple salts in $N, N^{\prime}$-dimethylformamide (DMF) and acetonitrile, which was important for the preparation of $\mathrm{CQ}$ complex salts, decreased as follows;

III-CQ $\approx \mathrm{N}-\mathrm{CQ}>$ II $-\mathrm{CQ} \gg \mathrm{I}-\mathrm{CQ} Z \mathrm{~V}-\mathrm{CQ}$

As a result, decrease in the resistivity by adding $\mathrm{CQ}^{\circ}$ molecules was considered to be caused by both piperadinium ring and $p$-xylylene group. It was presumed that $p$-xylylene group was effective for keeping the distance between ionic sites, increasing solubility of $\mathrm{CQ}$ simple salt, and forming the complexes of $\mathrm{CQ}^{\circ}$ and $\mathrm{CQ}^{=}$molecules, and piperadinium ring was effective for incresing electronic conduction by controlling the $\mathrm{CQ}^{\circ} \cdot \mathrm{CQ}^{*}$ arrangement against the cation. 